\title{
The Effect of Inflation, Exchange Rate and Yield of Retail Sukuk to Trade Volume of The Retail State Sukuk Series SR-007 in Secondary Market
}

\author{
Faraz Ayudia $^{1}$, Ummu Salma $^{2}$, Budi Permana Yusuf ${ }^{3}$ \\ \{alvarizhaayudiaf@gmail.com ${ }^{1}$, ummusalma@uhamka.ac.id², budi.permanajusuf@uhamka.ac.id ${ }^{3}$ \} \\ University of Muhammadiyah Prof Dr. Hamka, Indonesia ${ }^{123}$
}

\begin{abstract}
The research aims to determine the trading volumes of retail state sukuk that are thought to be influenced by macroeconomics through inflation indicators and the rupiah/USD exchange rate as well as retail yield sukuk itself. This research uses multiple regression methods with retail state sukuk SR-007 series as research objects. The results of the study in partial inflation and yield were positively significant as well as the significant negative exchange rates on the trading volumes of the retail state sukuk SR007 series. Simultaneously inflation, the exchange rate and the yield of retail sukuk have a significant influence on the trade volume of retail state Sukuk SR007 series. Regression Model shows R-squared adjusted value of 0.685428 This indicates inflation, the exchange rate and the yield of retail sukuk can explain the $68 \%$ of the dependent variable namely the trade Volume of retail state Sukuk series SR-007.
\end{abstract}

Keywords: Trade Volume, Retail Sukuk, Macroeconomics, Sukuk Yield.

\section{Introduction}

As stated in the Islamic Finance Report Country Report for Indonesia published by Islamic Research and Training Institute-Islamic Development Bank (IRTI-IDB), Thomson Reuters, and Global Islamic Financial Report [1], there is a huge opportunity and potential for Indonesia in developing Sharia financial products because Indonesia is the most Muslim countries. Sharia financial instruments that have been published either by the country or the company are Islamic bonds or Sukuk. Currently, some countries have become ordinary issuers Sukuk [2].

The state sukuk, or Sharia securities (SBSN) are one of the government's efforts in expanding Sharia finance products. The state Sukuk is the development of state securities instruments (SBN) based on sharia principles other than the State treasury, through Sukuk Negara being the government's step in closing the APBN deficit, short-term cash shortages, state cash accounts in the fiscal year [3].

State sukuk as state securities issued based on sharia principles, as evidence of the participation of SBSN assets in rupiah and foreign currencies, the definition is based on law Number 19 of 2008 [4]. In line with the increasing position of Indonesia as a middle-income country, so that the source of financing not only derived from good debt that can be obtained from foreign and domestic loans, but through the issuance of Sharia securities of the state (SBSN). The issuance of state sukuk is a government effort in reducing dependence on loans or debts both originating from domestic and foreign countries.

Sukuk retail is good for governments to raise funds to finance the sector borrowing funds from overseas and then exposed to exchange rate risk. Based on previous descriptions and 
analyses of Sukuk retail publishing, it is very interesting and useful to discuss the opportunities and challenges faced, so that Sukuk retail can perform better in the future [5].

According to [6] the lack of sales sukuk in retail investors became the reason the government expanded the spread of investors so that the secondary market was initially weak because of the scarcity of supply sukuk and the culture of hold to maturity can re-activate a sluggish secondary market. The government's seriousness in issuing state sukuk is evidenced by the continued variety of types of state sukuk instruments since its inception. Retail sukuk is one of the types of state sukuk instruments issued by the government, giving the community the opportunity to assist the government in alternative funding for ongoing infrastructure development [7].

For the successful Sukuk market, it is very important to have issuers and sharia-conscious investors. This is because in the context of asymmetric information and competition between Shariah scholars that proves Sukuk's compliance, the issuing company has a false incentive to lower compliance with strict Sharia standards [8]. Sukuk is a major transformation for Islamic institutions, in order to take advantage of sukuk, the sukuk market must be very dynamic [9]. The responsiveness of the market to the issuance of retail sukuk issued by the government can be seen from the total sales and rationing of retail sukuk that fluctuates from year to year. Compared to the conventional bond market, the sukuk market is more stable in the economy. In encouraging the development of sukuk markets, the government focused on macroeconomic policy design to maintain inflation and exchange rate stability [10]. According to [11] sukuk has become an important alternative to the real economy in terms of real sector financing. Sukuk contribute to inflation positively, this situation will be reflected in positive economic growth.

In 2015, the government set up a retail sukuk series SR-007 with a tenor of 3 years and due in 2018. Retail State Sukuk Allotment SR-007 series amounting to RP 21,965,035,000,000 with the number of investors as much as 29,706, after the retail Sukuk series SR-007 began to trade in the secondary market, bidding and sales activities fluctuate which means the Sukuk is active and highly liquid.

So this indicates a relatively high market interest and confidence in the retail sukuk. The responsiveness of the market to the issuance of retail sukuk issued by the government, which experienced this fluctuation is not only caused by the level of trade conducted by investors in both secondary and primary markets. Rather, macroeconomic factors and yield derived from the sukuk itself. One of the country's macroeconomic indicators is inflation and exchange rate. Discussions In the academic environment and practice, regarding the effect between sukuk retail and macroeconomics have been widely carried out [12].

According to [13] macroeconomic instability and the government's inability to control macroeconomic policies can be a measure of the occurrence of high levels of inflation. [14] revealed that the higher inflation rate will be the lower the trading volume of retail sukuk.

In addition, inflation can reduce or decrease the real value of money as a form of value of wealth [15]. [16] states that the inflation rate can explain the movement or trade of the state sukuk. Furthermore, according to [17] the exchange rate contributes to the bond prices, while the price of the bond may affect the yield or yield rate that indirectly encourages sukuk trade activity. The exchange rate and trade openness on the secondary market is a defining of sukuk market development [18]. The government needs to consider the effect of exchange rates on each economic policy, because the rate of exchange rates has a relationship to the capital market products that are sukuk in the long term [19].

According to [20] yield is the rate of return or profit expected by investors for investments made. Investor demand to buy sukuk will be influenced by yield. If the level of profit provided 
is higher then the investor will buy a sukuk, because it gives the expected return or expected profit. The yield is a reflection of the sukuk coupon itself, and the yield is inversely proportional to the price of the sukuk.

As for factors other than the macroeconomics described earlier, the yield level of the SR007 trade itself. [21] in his research stated that if retail sukuk yields affect the trading volume of sukuk itself, if trading volume increases, the sukuk yield level will increase. The yield will change if there are changes in prices traded in the secondary market in the opposite direction [22], Government securities yields have attracted investors' attention compared to the inflation rate in the country itself, if yields satisfy investors, they will buy state bonds [23].

Based on research [24] the exchange rate has a positive but not significant effect. Then research conducted [25] states there is no influence between inflation in state sukuk both in the long term and short term. While the exchange rate has a significant long-term influence on state sukuk. [26] in their research showed the results if Indonesia bond yield in the long run is influenced by inflation, US Bond yields of 10 years, and the exchange rate. The explanation above shows that there is a phenomenon gap, so the writer will conduct research to find out how much influence is caused by macroeconomic factors through inflation and the exchange rate as well as yield or the rate of return of the SR-007 series retail sukuk itself.

\section{Method}

The study used secondary data with multiple linear regression analysis methods, of which population and samples were obtained through the inflation monthly time series data, exchange rates, retail sukuk yield and trading volume of retail sukuk Seri SR-007-year 2015 to 2018. Inflation data and exchange rates are obtained through the website of Bank Indonesia (www.bi.go.id), while the retail yield sukuk and trade volume of the SR-007 series retail is obtained through the Ministry of Finance of the Republic of Indonesia.

In [14] said that if there is an increase in some goods and services only while at some time it will not necessarily be an inflation. The consumer price Index (CPI) is an indicator used to measure the inflation rate. The formula used to determine the rate of inflation based on the CPI indicator as follows:

$$
\begin{array}{ll} 
& \multicolumn{1}{l}{\pi=\frac{I H K t-I H K t-1}{I H K t-1} \times 100} \\
\text { Where: } & =\text { inflation rate } \\
\pi & =\text { t-period consumer price index } \\
\text { IHKt } & =\text { t-period consumer price index (past period). }
\end{array}
$$

The level of the exchange rate can affect an investor's decision in investing, when the rupiah is appreciated then the investor will choose the investment that uses the rupiah. Conversely, if the rupiah is depreciation, then investors tend to choose investments that use foreign currency to get a greater profit. According to [27] the exchange rate can be measured by:

$$
\text { Median Rate }=\frac{k j+k b}{2}
$$




$$
\begin{array}{ll}
\text { Where: } & \\
\mathrm{Kj} & =\text { Selling Rates } \\
\mathrm{Kb} & =\text { Buying Rate }
\end{array}
$$

According to [20] the yield is the rate of return or profit based on the yield expected by the investor on the investment made. Demand for investors to buy sukuk will be influenced yield.

The most widely used yield measurement is by using the yield to maturity. Because it can reflect the yield with a compound return level. Investors will reinvest income gained from bonds at the yield to maturity level [28], the following is the formula used in calculating the yield.

Where:

$$
y t m=c+\frac{\frac{F-P}{n}}{\frac{F+P}{2}} \times 100 \%
$$

$$
\begin{array}{ll}
y t m & =\text { yield to maturity } \\
C & =\text { coupon } \\
F & =\text { Sukuk par value } \\
P & =\text { Current sukuk price } \\
n & =\text { Number of years to maturity. }
\end{array}
$$

The research was assisted by E-views 10 in data processing, there was a descriptive statistical processing, multiple linear regression, classical assumption test, analysis of the correlation coefficient and determination, as well as the $\mathrm{F}$ test hypothesis and the $\mathrm{T}$ test. Referring to several findings above, the hypothesis is resulted as follows:

H1: Partially, inflation has a significant and significant effect on the trading volume of the retail sukuk SR-007 series.

$\mathrm{H} 2$ : Partially, the exchange rate has a significant and significant effect on the trading volume of the retail country sukuk series SR-007.

H3: Partially, retail sukuk yield has a significant and significant effect on the trading volume of retail sukuk SR-007 series

H4: Simultaneously, inflation, exchange rate and yield of retail sukuk have a significant and significant effect on the trading volume of retail sukuk SR-007.

\section{Result And Discussion}

Based on table 1, it can be seen that the average value during the observation period on the variable inflation rate is $4.408947 \%$, the exchange rate is Rp13.434, retail sukuk yield is $7.476053 \%$ and trading volume of sukuk retail country SR-007 series is Rp10,455.52 billion. The highest value on the variable inflation was $7.26 \%$, the exchange rate against the USD was Rp14,657, the retail sukuk yield was $9.22 \%$ and the trading volume of the SR-007 series retail state sukuk was Rp48,267.87 billion.

The lowest value of the inflation variable is $2.79 \%$, the exchange rate of the rupiah to USD amounted to Rp12, 887, a retail sukuk yield of $5.8 \%$ and a trading volume of Rp786 million. But the overall inflationary value tends to fluctuate and stabilize, the exchange rate has the 
movement that tends to stabilize and retail sukuk yield rate fluctuates while the trading volume of retail state Sukuk series SR-007 fluctuates heavily during the secondary market.

Table 1. Descriptive statistical results Date: 03/09/20 Time: $13: 38$ Sample: 2015M02 2018M0

\begin{tabular}{lcccc}
\hline \hline & INFLASI & KURS & YIELDSR007 & TVASR007 \\
Mean & 4.408947 & 13434.26 & 7.476053 & 10455.52 \\
Median & 3.770000 & 13349.00 & 7.415000 & 8302.116 \\
Maximum & 7.260000 & 14657.00 & 9.220000 & 48267.87 \\
Minimum & 2.790000 & 12887.00 & 5.840000 & 786.7450 \\
Std. Dev. & 1.443007 & 331.0401 & 0.848272 & 9926.282 \\
Skewness & 1.009123 & 1.306205 & -0.167587 & 2.047016 \\
Kurtosis & 2.458836 & 6.240593 & 2.263282 & 7.515240 \\
Jarque-Bera & 6.913110 & 27.43304 & 1.037233 & 58.81845 \\
Probability & 0.031538 & 0.000001 & 0.595344 & 0.000000 \\
& & & & \\
Sum & 167.5400 & 510502.0 & 284.0900 & 397309.7 \\
Sum Sq. Dev. & 77.04396 & 4054739. & 26.62391 & $3.65 \mathrm{E}+09$ \\
& & & & \\
Observations & 38 & 38 & 38 & 38
\end{tabular}

Based on the test results in table 2, it appears that there is no tolerance value that is less than 0.10 , tolerance values range from 0.122276 to 0.550048 between independent variables. Likewise, with the VIF value no value greater than 10, the VIF value can be seen in the Centered VIF column ranging from 1.226250 to 1.73190 , it can be concluded that there are no multicollinearity problems in the regression model.

\begin{tabular}{|c|c|c|c|}
\hline \multicolumn{4}{|c|}{. Multicollin } \\
\hline & INFLASI & KURS & YIELDSR007 \\
\hline $\begin{array}{l}\text { INFLASI } \\
\text { KURS }\end{array}$ & 1.000000 & 0.122276 & 0.550048 \\
\hline KURS & 0.122276 & 1.000000 & 0.411140 \\
\hline YIELDSR007 & 0.550048 & 0.411140 & 1.000000 \\
\hline \multirow{4}{*}{\multicolumn{4}{|c|}{$\begin{array}{l}\text { Variance Inflation Factors } \\
\text { Date: 03/09/20 Time: } 13: 59 \\
\text { Sample: 2015M02 2018M03 } \\
\text { Included observations: } 38\end{array}$}} \\
\hline & & & \\
\hline & & & \\
\hline & & & \\
\hline Variable & $\begin{array}{l}\text { Coefficient } \\
\text { Variance }\end{array}$ & $\begin{array}{l}\text { Uncentered } \\
\text { VIF }\end{array}$ & $\begin{array}{c}\text { Centered } \\
\text { VIF }\end{array}$ \\
\hline & & & \\
\hline C & $1.45 E+09$ & 1780.985 & NA \\
\hline INFLASI & 587766.0 & 15.46863 & 1.460999 \\
\hline KURS & 9.373658 & 2075.315 & 1.226250 \\
\hline YIELDSR007 & 2016260 . & 139.8917 & 1.731910 \\
\hline
\end{tabular}

Based on the calculation results in table 3, it can be seen that the regression model does not indicate the existence of autocorrelation. Evidenced by the F-Statistic Probability value of 0.8731 and Chi-Square Probability value at Obs * R-Squared of 0.8517 which means the value is greater than 0.05 and not significant at $\alpha 5 \%$.

Table 3. Autocorrelation Test Breusch-Godfrey Serial Correlation LM Test:

\begin{tabular}{lrll}
\multicolumn{4}{l}{ Breusch-Godfrey Serial Correlation LM Test: } \\
\hline \hline F-statistic & 0.136294 & Prob. F $(2,32)$ & 0.8731 \\
Obs*R-squared & 0.320964 & Prob. Chi-Square(2) & 0.8517 \\
\hline \hline
\end{tabular}

In the output of table 4 , it can be seen that the probability value in this regression model is 0.101221 , which means it has a value greater than 0.05 according to decision making criteria. Then it means that all the data in the regression model with inflation independent variables, 
the exchange rate and retail sukuk yields can meet the assumption of normality, because the data are normally distributed.

Table 4. Normality Test

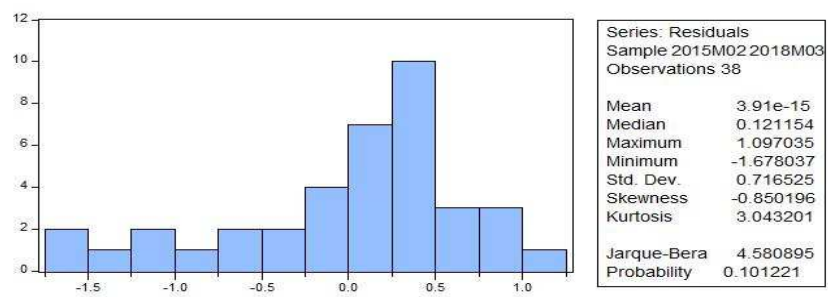

The test results in table 5 using the White Test can be seen that the F-Statistic Probability value is 0.4954 and the Chi-Square Probability value on Obs * R-Squared is 0.4468 . This value is not significant according to the decision-making criteria, which is greater than 0.05 , this indicates that there is no heteroscedasticity in the regression model.

Table 5. Heteroscedasticity Test

\begin{tabular}{llll} 
Heteroskedasticity Test White & & & \\
\hline \hline F-statistic & 0.945975 & Prob. F(8,29) & 0.4954 \\
Obs R-Rquared & 7.864197 & Prob. Chi-Square(8) & 0.4468 \\
Scaled explained SS & 6.431706 & Prob. Chi-Square(8) & 0.5990 \\
\hline \hline
\end{tabular}

Based on table 6, the regression model formed in this study is as follows: Y $=178056.7+4195.517 \mathrm{X} 1-15.66008 \mathrm{X} 2+3248.045 \mathrm{X} 3$

Information:

y (TVASR007)

$=$ SR-007 Series Retail Sukuk Country Trading Volume

X1 (INFLATION)

$=$ Inflation

X2 (EXCHANGE)

$=$ Exchange Rates

X3 (YIELDSR007)

$=$ Retail Sukuk Yield

$\mathrm{T}$ test results show that inflation and sukuk yield have a significant positive effect on the retail volume of the sukuk retail country SR-007 series. It can be seen that inflation has a tvalue of $5.472468>\mathrm{t}$-table of 2.032 and sukuk yield of t-value of $2.287435>\mathrm{t}$-table of 2.032 with a significance of $<\alpha=5 \%$. The exchange rate can have a significant negative effect on the trading volume of the retail sukuk SR-007 series. It can be seen that the t-value of $5.114926<\mathrm{t}$-table is 2.032 with a significance of $0.0000<\alpha=5 \%$.

The output results in table 6 , show that the F test, Simultaneously inflation, the exchange rate and sukuk yield affect the trading volume of the state sukuk retail series SR-007, with an $\mathrm{F}$ value of $27.87339>\mathrm{F}$ table 2.88 with a significance level of 0.0000 . 
Table 6. Multiple Linear Analysis, T Test, F Test, and Correlation and Determination Coefficient Tests

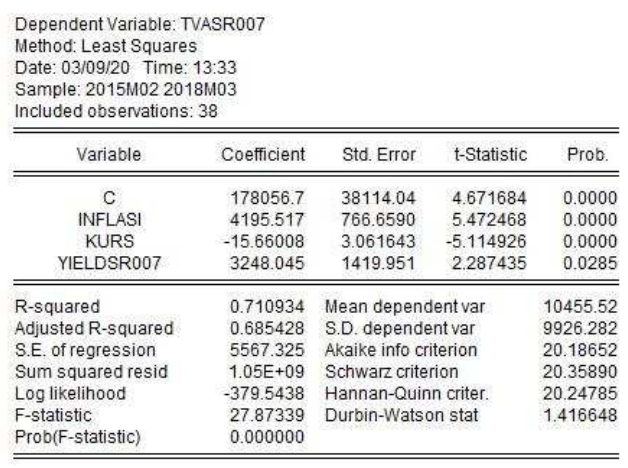

Based on table 6 , the R-Square value obtained is 0.710934 so that the double correlation value can be calculated with the root R-Square value with a result of 0.843169022 or $84.3 \%$ then it shows the level of a very strong relationship between inflation variables, the exchange rate and retail sukuk yield with SR-007 series retail sukuk trading volume. The adjusted R2 value obtained is 0.685428 . This shows that the inflation rate, exchange rate and retail sukuk yield can explain the trading volume of the retail sukuk SR-007 series by $68 \%$ and the rest is explained by other variables.

Inflation rates and yields of state sukuk have a positive effect on the trading volume of retail sukuk SR-007 series, inflation fluctuations remain stable and tend to decline so that the country's economy is stable, investors will be interested in investing in sukuk, the results show that high inflation can increase sukuk trade volume Country Retail Series SR-007.

While the yield rate shows fluctuation tends to increase so that the higher the yield or sukuk yield, the more sought after by investors, the yield of the sukuk itself will affect the series of sukuk being traded on the secondary market. However, the exchange rate has a negative effect on the trading volume of the retail sukuk SR-007 series. During the research period the exchange rate experienced an increase and the rupiah weakened or depreciated, so there was a decrease in trading volume because investors preferred to invest in instruments using the dollar.

In the first hypothesis "in assume there is a significant positive influence between inflation on the trade volume of the SR-007 series retail state. Based on the results of calculations and analyses above the first hypothesis can prove Results indicate that high levels of inflation can be Increase the trade volume of retail state Sukuk series SR-007 on the market Secondary.

The level of inflation in the research period from 2015 to 2018 indicates fluctuating rate of inflation but remains stable tend to decline by an average of $4.40 \%$. Investors in secondary markets need to pay attention to inflation rates when Will sell and buy SR-007, as there are positive influences that significant inflation rates. This research supports previous research conducted by [23], [29], [30], and [31] who also declared inflation positive effect on sukuk trade volumes. So, if the level inflation increases it will affect the volume of trading sukuk. However These results are not in accordance with [32] and [21] which states inflation has a negative effect on sukuk trade volumes.

The hypothesis done in this research is "in assume there are significant positive influence between the volume exchange rate on Sukuk trade SR-007 Series Publishing State ". Based on the results of calculations and analysis if the second hypothesis is not proven, results obtained based on data analysis products that the Rupiah exchange rate has depreciation against the 
USD during the research period, the increase in Rupiah exchange rate against the USD resulting in decreased trading volumes. The exchange rate has an influence with the trade volume of the SR-007 series issuance, the assumption in the second hypothesis cannot be proved, because the value obtained is not positive but negative significantly towards the trading volume.

The most appreciable exchange rate of the Rupiah will encourage investors in buy and sell SR-007 so that the trading volume is active. But it will during the reverse period of research and stable exchange rate movements So that investors are not interested in diversifying their wealth on financial assets Its exchange value Sell. This results in accordance with the research [23], [33], [24], and [31] who If the exchange rate has no positive influence on the volume of the Sukuk trade in the secondary market. Unlike the research conducted by [32], [34], and [35] who stated that the exchange rate positively affects Sukuk's trading volume in the market Secondary.

The third hypothesis contained in this study is "Assumed There is a significant positive influence between retail sukuk yields on the trading volume of retail sukuk SR-007 series. Based on the results of calculations and analysis, there are results that the third hypothesis is proven. The results obtained indicate that the yield value of retail sukuk fluctuates so that it has a significant positive effect on the trading volume of sukuk in the secondary market.

The higher the return or yield of the sukuk, the more sought by investors, the yield of the sukuk itself will affect the series of sukuk being traded on the secondary market. The results of this study support research previously conducted by [21] and [36] that the yield of retail sukuk has an influence on the trading volume of sukuk in the secondary market. However, research [32] and [23] have no influence on trading volume in the secondary market.

The final hypothesis in this study "It is assumed that there is a significant influence between inflation, the exchange rate and retail sukuk yields on the trading volume of the SR007 series retail state sukuk". Based on the results of calculations and analysis, this fourth hypothesis can be accepted and proven, with a significance value smaller than $\alpha$ of $5 \%$. There is a significance between the three independent variables, so it explains that inflation, exchange rate and yield of retail sukuk have a joint influence on the trading volume of retail country sukuk series SR-007.

\section{Conclusion}

The conclusions of this study are as follows: (1) Based on the results of the study that the inflation rate has a significant positive effect that will increase the trading volume of SR-007. (2) The results of the study show that the exchange rate has a significant negative effect that the increased exchange rate will reduce the trading volume in SR-007. (3) Based on the research results of the state sukuk yields have a significant positive effect, which means an increase in yield will encourage trade volume. (4) Simultaneously, based on the results of the study indicate that the inflation rate, exchange rate and sukuk yield significantly influence the trade volume.

Market participants or investors are expected to pay attention to inflation rates, exchange rates and state sukuk yields through this research in making decisions when offering or selling investment products, especially state sukuk in the secondary market.

In this study there are still limitations: (1) This study only uses the SR-007 series, not using the entire series in retail sukuk. (2) Macroeconomic indicators used are only inflation 
and exchange rates, more macroeconomic variables need to be used so that this research is more accurate and specific. (3) The research period is limited to only 3 years, starting in 2015 to 2018 in accordance with the SR-007 series retail sukuk that are due.

\section{References}

[1] M. A. Omar, "Islamic Finance Report Country for Indonesia," in General for Islamic Research and Training Institute of Islamic Development Bank, 2016.

[2] P. S. Prabowo, "If the Variable Retail Sukuk Issuance of Government Influence," Spirit Pro Patria, vol. III, no. 1, pp. 68-77, 2017.

[3] R. Q. Mitsaliyandito and T. Arundina, "Dynamic Relationship between Sovereign Bond and Sukuk Market Developments in Indonesia," J. Soc. Sci. Humanit., vol. 26, p. 27, 2018.

[4] Direktorat Pembiayaan Syariah, Kumpulan Peraturan Surat Berharga Syariah Negara. DJPPR Kementerian Keuangan RI, 2017.

[5] R. Sukmana, "A critical assessment of retail sovereign sukuk in Indonesia," Qual. Res. Financ. Mark., vol. 12, no. 2, pp. 243-262, 2019, doi: 10.1108/QRFM-10-2018-0109.

[6] A. Ulusoy and M. Ela, "Secondary Market of Sukuk: An Overview," Int. J. Islam. Econ. Financ. Stud., vol. Vol: 2, 2017.

[7] I. Amaliah and T. Aspiranti, "State Sukuk Potential in Reducing Indonesia Budget Deficit, 2009-2015," J. Econ. Bus. Account. Ventur., vol. 20, no. 1, p. 21, 2017, doi: 10.14414/jebav.v20i1.781.

[8] A. Duqi and H. Al-Tamimi, "Factors affecting investors' decision regarding investment in Islamic Sukuk," Qual. Res. Financ. Mark., vol. 11, no. 1, pp. 60-72, 2019, doi: 10.1108/QRFM-01-2018-0009.

[9] B. Uddin and A. Hamat, "Ibn Khaldun' s Economic Thought: A Role Model for Sukuk Market," vol. 4, no. April, pp. 213-231, 2019.

[10] Suriani, M. S. A. Majid, R. Masbar, and N. A. Wahid, "Macroeconomic Determinants of the Capital Market in Indonesia: A Comparative Analysis between Sukuk and Bonds Markets," Int. J. Acad. Res. Econ. Manag. Sci., vol. 7, no. 2, pp. 1-17, 2018, doi: 10.6007/IJAREMS/v7i2/4112.

[11] H. B. Kantarc1 and T. Eren, "The Emergence of Sukuk Market and Economic Effects," GJETeMCP) An Online Int. Res. J., vol. 4, p. 1, 2018.

[12] R. Y. Astuti and A. A. B. Fani, "Risk and Return of Retail Sukuk and Retail Bond in Indonesia Period 2008-2017 (Comparative Study)," AKSES J. Ekon. dan Bisnis, vol. 15, no. 1, pp. 32-44, 2020, doi: 10.31942/akses.v15i1.3359.

[13] A. Karim, Ekonomi Makro Islam. Jakarta: Rajagrafindo Persada, 2014.

[14] A. Manab and A. E. Sujianto, Pengaruh Stabilitas Ekonomi Makro Terhadap Penerbitan Sukuk Negara Di Indonesia, Malaysia dan Brunei Darussalam. Tulungagung: Cahaya Abadi, 2016.

[15] S. Sukirno, Makroekonomi Teori Pengantar. Jakarta: Rajagrafindo Persada, 2016.

[16] M. Puspa and J. Duasa, "Sovereign Sukuk Pricing Analysis: Do Macroeconomic Variables Matter?," IIUM J. Econ. Manag., vol. 25, no. 3, pp. 513-528, 2017.

[17] B. Francova, "Valuation of government bonds: The exchange rate is an important aspect," Acta Univ. Agric. Silvic. Mendelianae Brun., vol. 65, no. 6, pp. 1911-1916, 2017, doi: 10.11118/actaun201765061911.

[18] A. M. Al-Raeai, Z. Zainol, and A. K. A. Rahim, "The influence of macroeconomics factors and political risk on the sukuk market development in selected GCC countries: A panel data analysis," J. Ekon. Malaysia, vol. 53, no. 2, 2019, doi: 10.17576/JEM-2019-5302-15.

[19] H. Arshad, R. Muda, and I. Osman, "Impact of exchange rate and oil price on the yield of sovereign bond and sukuk: Evidence from Malaysian capital market," J. ofEmerging Econ. Islam. Res., vol. 5, no. July 2013, pp. 27-41, 2018.

[20] A. Nariman, "Pengaruh Faktor Internal dan Faktor Eksternal Perushaan Terhadap Yield to 
Maturity Obligasi Korporasi yang Terdaftar di Bursa Efek Indonesia,” 2016.

[21] R. Yusiarmayanti, "Faktor-Faktor yang Memengaruhi Volume Perdagangan Sukuk Negara Ritel SR-005 Di Indonesia 2013-2016," 2017.

[22] C. Y. Sefriyani, Purnomo, and I. Hariyani, Capital Market: Top Secret. Penerbit ANDI, 2017.

[23] B. B. Tjandrasa, "The Effect of Consumer Expectation Index, Economic Condition Index and Crude Oil Price on Indonesian Government Bond Yield," J. Econ. Bus. Account. Ventur., vol. 20, no. 1, p. 1, 2017, doi: 10.14414/jebav.v20i1.935.

[24] H. Smaoui and M. Khawaja, "The Determinants of Sukuk Market Development," Emerg. Mark. Financ. Trade, vol. 53, no. 7, pp. 1501-1518, 2017, doi: 10.1080/1540496X.2016.1224175.

[25] J. Juaris, R. Masbar, and C. Seftarita, "Analysis of The Effect of Monetary Policy on Government Sharia Securities (SBSN) in Indonesia," Sriwij. Int. J. Dyn. Econ. Bus., vol. 2, no. 2, p. 109, 2018, doi: 10.29259/sijdeb.v2i2.109-122.

[26] A. D. Prasetyo and Y. Achlanudin, "The Effect of Inflation, US Bond Yiled and Exchange Rate on Indonesia Bond Yield," J. Perspekt. Pembiayaan dan Pembang. Drh., vol. 6, no. 6, 2019.

[27] M. Ekananda, Ekonomi Internasional. Jakarta: Erlangga, 2014.

[28] I. Masitoh, “Analisis Pengaruh Likuiditas Terhadap Yield Spread Sukuk,” 2016.

[29] A. Yusuf and A. D. Prasetyo, "The effect of inflation, US bond yield, and exchange rate on Indonesia bond yield," J. Perspekt. Pembiayaan dan Pembang. Drh., vol. 6, no. 6, pp. 649-656, 2019, doi: 10.22437 ppd.v6i6.6853.

[30] S. A. Suciningtias, "Macroeconomic Impacts on Sukuk Performance in Indonesia: Cointegration and Vector Error Correction Model Approach," vol. 8, pp. 117-130, 2019.

[31] L. F. Ni'mah and A. S. Pratomo, "Analisis Determinan Volume Perdagangan Sukuk Negara Ritel Seri Sr-007," El Dinar, vol. 7, no. 2, p. 119, 2019, doi: 10.18860/ed.v7i2.6685.

[32] C. Utama and S. S. Agesy, "the Effect of Macroeconomic Variables on the Yield Spread of Indonesian Government'S Bond," J. Indones. Appl. Econ., vol. 6, no. 2, pp. 155-175, 2016, doi: 10.21776/ub.jiae.2016.006.02.2.

[33] A. C. Dewi, "Pengaruh Faktor-Faktor Makroekonomi Terhadap Pertumbuhan Surat Berharga Syariah Negara (SBSN) di Indonesia," Skripsi, 2017.

[34] F. Rahman, "Analisis Faktor-Faktor Makroekonomi yang Mempengaruhi Penerbitan Sukuk dan Obligasi Korporasi di Indonesia," 2017.

[35] R. Fauzi, "Pengaruh Inflasi, BI Rate, Nilai Tukar Terhadap Volume Transaksi Surat Berharga Syariah Negara di Indonesia 2014-2017," 2018.

[36] Q. Amali, “Analisis Faktor-Faktor yang Mepengaruhi Volume Perdagangan Sukuk Negara Ritel SR-006 di Indonesia," 2018. 